\title{
Perbandingan Efektifitas Larutan Antiseptik Kombinasi Chlorexidine Gluconate Cetrimide - Alkohol 70\% Dengan Povidone Iodine $10 \%$ Terhadap Kepadatan Kuman Pada Tindakan Anestesi Spinal
}

Comparison of the effect of Antiseptic Solution Chlorexidine Gluconate Cetrimide Combined Alcohol 70\% And Povidone Iodine 10\% To bacterial density In Spinal Anesthesia Procedure

Khadafi Indrawan $\bigotimes^{*}$, Wiwi Jaya*, Noorhamdani **

*Bagian Anestesiologi dan Terapi Intensif RSUD Saiful Anwar/Fakultas Kedokteran Universitas Brawijaya Malang

** Bagian Mikrobiologi Fakultas Kedokteran,Universitas Brawijaya Malang

$\triangle$ Korespondensi/correspondence : Khadafi1012@gmail.com

\section{ABSTRACT}

Background : Bacterial infections can be caused by neuraxial technique. The Etiologic of Bacterial infection are use equipment, wrong aseptic techniques, or the type of used antiseptic solution. Antiseptic solution commonly used in spinal anesthesia are a povidone iodine and chlorhexidine. Chlorhexidine gluconate solution is a powerful antiseptic solution and has broad spectrum effect, and effective against almost all of the bacteria (Gram-positive and Gram-negative) and nosocomial fungi. Povidone iodine has a activity to killed gram negative and positive microorganisms and can can penetrate cell wall then inhibits bacterial synthesis of protein

objective : understanding in effectivity of combination Chlorhexdine gluconate cetrimide-alcohol 70\% compare to Povidone iodine 10\% to bacterial density In spinal anesthesia

Methods : This design of this study was single blind true experimental in 32 with patients aged of 18-40 years oid, with physical status ASA I-II who underwent spinal anesthesia. This study of two groups : Chlorexidine gluconate cetrimide-alcohol $70 \%$ group (clor) and Povidone Iodine 10\% group (pov). First Swab was taken from the patient before treatment, second swab was taken after treatment. Cerebrospinal fluid be also aspirated for culture. The results were analyzed with paired sample t test (before and after the treatment) and independent sample t test (after treatment), and pvalue $<$ 0,05 was considered significant.

Results : The incidence of bacterial density in Chlorexidine group 1,4\% and in povidone group was 4,1\%. The bacterial density incidence was more frequent in the Povidone group than chloreidine group. Mean of bacterial density after the treatment in the group Chlorexidine was 0.0625, whereas the Povidone group was 1,0625. The decrease of bacterial density in the clor group is lower then povidone iodine.

Conclusion : Antiseptic solution of Chlorexidine gluconate cetrimide combine with 
alcohol $70 \%$ is more effective than povidone iodine in reducing bacterial density after spinal anesthesia

Key words : Antiseptic solution, Bacterial density, Chlorexidine, Povidone iodine.

\section{ABSTRAK}

Latar belakang : Infeksi bakteri dapat disebabkan oleh tehnik neuraxial. Salah satu faktor penyebab infeksi bakteri adalah peralatan yang digunakan, tehnik aseptik yang salah, atau larutan anti septik yang dipakai. Larutan antiseptik yang biasa digunakan pada anestesi spinal adalah chlorhexidine dan povidone iodine. Chlorhexidine gluconate adalah larutan antiseptik yang kuat dan berspektrum luas, efektif melawan hampir semua bakteri (gram positif dan gram negatif) dan jamur nosokomial . Povidone iodine memiliki aktivitas melawan mikroorganisme b gram negatif maupun gram postif dan dapat menembus dinding sel serta menghambat sintesis protein bakteri

Tujuan : Mengetahui Efektifitas larutan antiseptik kombinasi Chlorhexdine gluconate cetrimide - alkohol 70\% dengan pemakaian Povidone iodine 10\% terhadap kepadatan kuman pada tindakan anestesi spinal

Metode : Penelitian eksperimental dengan rancangan "single blind true experimental design" pada 32 pasien dengan usia 18 - 40 tahun, status fisik ASA I-II yang menjalani tindakan anestesi spinal. Terdiri dari 2 kelompok: kelompok Chlorexidine gluconate cetrimide-alkohol 70\% (clor) dan kelompok Povidone Iodine 10\% (pov). Dilakukan pengambilan swab I pada punggung pasien sebelum perlakuan. Dan pengambilan swab II setelah mendapat perlakuan dan mengambil cairan serebrospinal untuk dikultur. Analisa hasil dengan uji statistik dilakukan uji beda t berpasangan (sebelum dan sesudah perlakuan) dan uji t dua sampel bebas (sesudah perlakuan), dengan derajat kemaknaan yaitu nilai $p<0,05$.

Hasil : Insidensi kepadatan kuman pada kelompok clor sebesar 1,4\% sedangkan pada kelompok pov 4,1\%. Insidensi kepadatan kuman lebih banyak pada kelompok povidone iodine. Dari rata-rata penurunan kepadatan kuman sesudah perlakuan kelompok chlorexidine mean $=0,0625$, sedangkan pada kelompok povidone mean $=1,0625$. Ratarata penurunan kepadatan kuman pada kelompok chlorexidine lebih kecil.

Simpulan : Efektifitas antiseptik kombinasi Chlorexidine gluconate cetrimide-alkohol 70 $\%$ lebih baik bila dibandingkan antiseptik Povidone iodine 10\% terhadap kepadatan kuman pada tindakan anestesi spinal.

Kata kunci : Chlorexidine, kepadatan kuman, larutan antiseptik, Povidone iodine

\section{PENDAHULUAN}

Infeksi bakteri yang disebabkan oleh tehnik neuraxial dapat menyebabkan abses, meningitis, dan arachnoiditis pada daerah dimana 
metode tehnik tersebut diaplikasikan. Salah satu faktor penyebab infeksi bakteri adalah peralatan yang digunakan, tehnik aseptik yang salah, atau larutan anti septik yang digunakan. Sumber utama yang sering menimbulkan infeksi bakteri adalah penularan dari kulit pasien atau dari flora kulit pasien. Dalam hal infeksi, penyebab utama sering di dominasi oleh species Staphylococcus terutama Staphylococcus aureus dan Staphylococcus epidermidis. ${ }^{1}$

Salah satu pencegahan komplikasi infeksi karena tindakan regional anestesi adalah menggunakan larutan antiseptik. Penggunaan larutan antiseptik yang lazim dipakai untuk tindakan regional anestesi di RSU Saiful Anwar Malang adalah savlon (kombinasi chlorhexidine gluconate cetrimide dengan alkohol $70 \%$ ), atau dengan povidone iodine $10 \%$. Hal ini mendorong untuk dilakukan penelitian efektifitas penggunaan larutan antiseptik antara kombinasi Dari penelitian sebelumnya Lee et al pada tahun 2010 melakukan pengujian terhadap efektifitas dari chlorhexidine dan povidone iodine untuk pre operatif antiseptik dalam hal mencegah infeksi karena tindakan pembedahan, diperoleh kesimpulan bahwa antiseptik pre operatif dengan chlorexidine lebih efektif daripada menggunakan iodine untuk mencegah infeksi karena tindakan pembedahan . ${ }^{3}$

Pada penelitian yang dilakukan
Atul P kulkani, Meneliti perbandingan efektifitas antara chlorhexidine $2 \%$ yang di kombinasi chlorhexidine gluconate cetrimide - alkohol $70 \%$ dengan providone iodine $10 \%$.

Larutan antiseptik yang digunakan untuk anestesi regional saat ini masih dalam kontroversi, baik dalam pemilihan larutan antiseptik yang paling sesuai dan aman untuk dipakai sebelum blok regional. Karakeristik esensial dari antiseptik yang ideal meliputi (1) efektif membunuh mikroorganisme dengan spektrum yang luas, (2) onset dan efikasinya cepat, (3) efeknya lama, (4) tidak ada inaktivasi material organik (darah, pus, dan cairan tubuh), dan (5) efek toksiknya minimal terhadap kulit (Hebl, 2006). Beberapa larutan yang sering digunakan meliputi povidone iodine (i.e., Betadine; Purdue Pharma, Stamford, CT), chlorhexidine gluconate (i.e., Hibiclens; Regent Medical, Norcross, GA), chlorehexidine cetrimide (Savlon), dan Alkohol $70 \%{ }^{2}$

alkohol dan povidone iodine $10 \%$ untuk disinfeksi kulit pada pemasangan central venous catheter (CVC) dan epidural. Kesimpulan dari penelitian ini bahwa tidak ada perbedaaan yang berarti antara penggunaan chlorhexidine gluconate yang dikombinasi dengan alkohol dan, povidone iodine $10 \%$ baik pada efikasi, harga maupun efek samping. chlorhexidine $2 \%$ memiliki exposure time yang lebih pendek, dan dapat 
digunakan dalam situasi emergensi. Pada data epidemiologi diketahui rendahnya kejadian infeksi, timbulnya efek residual dan efek bakterisidal chlorhexidine terhadap Staphylococcus membuat chlorhexidine lebih disukai sebagai larutan antiseptik. ${ }^{4}$

Penelitian ini bertujuan untuk mengetahui efektifitas penggunaan larutan antiseptik antara kombinasi chlorhexidine cetrimide-alkohol $70 \%$ dan povidone Iodine $10 \%$ dan mengetahui larutan mana yang lebih baik untuk digunakan pada tindakan anestesi spinal di RSU Saiful Anwar Malang. Penggunaan antiseptik ini erat kaitannya dengan program pencegahan infeksi dan standar pelayanan di rumah sakit yang mengutamakan keselamatan pasien (patient safety).

\section{METODE}

Penelitian ini dilakukan menggunakan rancangan penelitian dengan true experimental design yang terdiri dari 2 kelompok sampel bebas, yaitu kelompok pertama Chlorhexidine gluconate cetrimide - alkohol $70 \%$ dengan kelompok kedua povidone iodine $10 \%$ dilakukan dengan single blind.

Pasien yang diteliti diambil
berdasarkan simple random
sampling .Design eksperimental yang
dilakukan pada perhitungan kepadatan
kuman dengan swab lidi steril dengan
pre test-post test control group design.

Penelitian dilakukan di kamar operasi bedah sentral RSUD dr.Saiful Anwar Malang. Pengujian laboratorik dikerjakan di laboratorium mikrobiologi FK UNIBRAW Malang. Penelitian dilakukan setelah mendapat persetujuan dari panitia tetap Penilai Etik penelitian FK UNIBRAW Malang bersedia menjadi peserta penelitian dan memahami aturan-aturan penelitian dan persetujuan tertulis dari pasien yang telah mendapat penjelasan. Kriteria inklusi adalah pasien laki-laki atau perempuan yang menjalani tindakan anestesi spinal, Pasien bukan kontraindikasi dilakukan tindakan anestesi spinal, Usia 18 - 40 tahun, BMI (Body Mass Index) $=18,5-25 \mathrm{~kg} /$ $\mathrm{m}^{2}$, Status fisik ASA I-II

Pemilihan sample dilakukan dengan purposive sampling dengan jumlah sampel yang diperlukan adalah 32 sampel, yang dibagi menjadi dua kelompok dimana masing-masing kelopok berjumlah 16 sampel.

Pasien yang telah memenuhi kriteria penelitian dilakukan swab kulit yang pertama pada kulit yang akan dilakukan tindakan regional anestesi dengan menggunakan lidi steril. Hasil swab I kemudian dikultur sebagai biakan I. Kemudian dilakukan prosedur disinfeksi dengan larutan kombinasi chlorhexidine gluconate cetrimide alkohol 70\%, dan dibiarkan selama 1 menit. atau dengan povidone iodine $10 \%$, kemudian dibiarkan selama 1 menit. Setelah itu dilakukan swab kulit yang kedua dengan menggunakann lidi 
steril, hasil nya kemudian dibiakkan sebagai biakan II.

Seluruh media pembiakan yang telah ditanam dikirimkan ke laboratorium mikrobiologi FK UNIBRAW untuk dibiakkan selama 24 jam pada suhu $37^{\circ} \mathrm{C}$. selanjutnya dilakukan penghitungan koloni kuman yang timbul (dengan maksimum 300 koloni, bila lebih dinyatakan sebagai padat). Hasil tentang jumlah kuman kemudian dianalisis, ditentukan secara kuantitatif penurunan tingkat kepadatan kuman setelah dilakukan desinfeksi.

Data yang terkumpul dilakukan analisis dengan menggunakan SPSS versi 21. Analisis hasil dengan uji statistik, pada uji statistik 1 dilakukan uji beda $t$ berpasangan dengan membandingkan kepadatan kuman sebelum dan pasca perlakuan pada kedua kelompok. Pada uji statistik 2 dilakukan uji independen sample $\mathrm{t}$ tes, membandingkan hasil kepadatan kuman pada swab ke 2 atau pasca perlakuan terhadap kedua kelompok (kelompok larutan kombinasi Chlorexidine gluconate cetrimide Alkohol 70\% dan kelompok larutan povidone iodine $10 \%$ ).

\section{HASIL}

Telah dilakukan penelitian pemberian larutan kombinasi Chlorexidine gluconate cetrimide alkohol $70 \%$ dengan pemakaian Povidone iodine $10 \%$ terhadap kepadatan kuman pada tindakan anestesi spinal pada 32 pasien dengan kriteria inklusi dan eksklusi tertentu serta bersedia untuk mengikuti penelitian ini. Pasien dibagi menjadi dua kelompok, yaitu kelompok larutan kombinasi Chloreidine gluconate cetrimide - alkohol $70 \%$ (clor) dan larutan Povidone iodine $10 \%$ (pov).

Pada Tabel 1, dari 16 sampel kelompok clor didapatkan, 4 koloni kuman >300 (nomor sampel 11,16, 24 dan 26), pada swab II 1 kelompok tersisa 1 koloni kuman (nomor sampel 11), dan kelompok lainnya steril atau tidak ditemukan kuman. Tidak ditemukannya adanya koloni kuman pada cairan serebrospinal (CSF) pada kelompok kombinasi Chlorexidine gluconate cetrimide - alcohol 10\%.

Pada gambar 1, adalah foto koloni kuman pada kelompok clor pada nomer sampel 11 dan 16 dimana pada swab 1 terdapat jumlah koloni kuman lebih dari 300. Pada foto koloni kuman nomer 11 swab ke 2 masih didapatkan 1 koloni kuman.

Dari tabel 2 dari 16 sampel kelompok (pov) didapatkan, pada swab I terdapat 2 koloni kuman $>300$ (nomor sampel 6 dan 13), dan pada swab II kedua kelompok masih memiliki 4 koloni kuman (nomor sampel 6) dan 8 koloni kuman (nomor sampel 13). Pada kelompok (pov) swab II setelah perlakuan dari 16 sampel penelitian terdapat 4 kelompok yang masih terdapat koloni kuman, yaitu pada nomor sampel 1,5,6,13 
Tabel 1. Hasil Perhitungan kepadatan kuman kelompok clorexidine-alkohol

\begin{tabular}{llll}
\hline NO SAMPEL & SWAB 1 & SWAB 2 & CSF \\
\hline 2 & 7 & 0 & 0 \\
\hline 3 & 4 & 0 & 0 \\
\hline 4 & 10 & 0 & 0 \\
\hline 7 & 217 & 0 & 0 \\
\hline 11 & $>>300$ & 1 & 0 \\
\hline 14 & 8 & 0 & 0 \\
\hline 15 & 1 & 0 & 0 \\
\hline 16 & $>>300$ & 0 & 0 \\
\hline 17 & 20 & 0 & 0 \\
\hline 21 & 0 & 0 & 0 \\
\hline 22 & 17 & 0 & 0 \\
\hline 23 & 4 & 0 & 0 \\
\hline 24 & 0 & 0 & 0 \\
\hline 25 & $>>300$ & 0 & 0 \\
\hline 26 & 3 & 0 & 0 \\
\hline
\end{tabular}

Keterangan : Swab 1 : sebelum diberi perlakuan, Swab 2 : setelah diberi perlakuan, CSF : dilakukan pengambilan cairan cerebrospinal dan dikulturkan
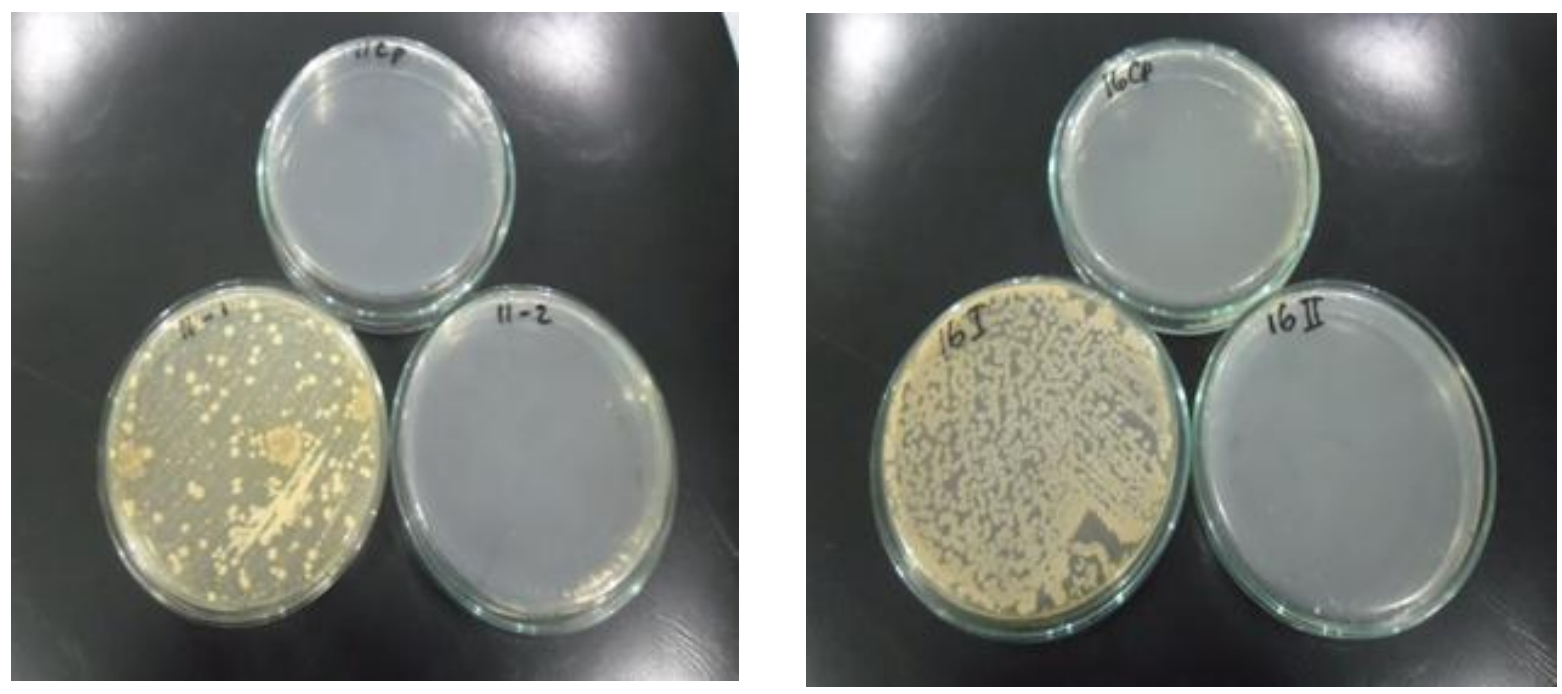

Gambar 1. Koloni kuman kelompok (clor), nomor sampel 11 dan 16 
Pada gambar 2 adalah foto koloni kuman pada kelompok pov pada nomer sampel 6 dan 13 dimana pada swab 1 terdapat jumlah koloni kuman lebih dari 300, dan pada swab ke 2 pada nomer sampel 6 masih terdapat 4 koloni kuman, pada nomer sampel 13 masih terdapat 8 koloni kuman.

Pada Tabel 3, dapat dilihat bahwa hasil uji $t$ tes berpasangan membandingkan kepadatan kuman sebelum dan pasca perlakuan. Pada kelompok larutan kombinasi Chlorexidine gluconate cetrimide alcohol $70 \%$ (clor) menunjukkan nilai $\mathrm{p}$ $<0,05(\mathrm{p}=0,014)$, dan pada kelompok Povidone iodine $10 \quad \% \quad$ (pov) menunjukkan hasil $\mathrm{P}<0,05 \quad(\mathrm{P}=$ 0,041). Hal ini menunjukkan bahwa ada perbedaan yang bermakna pada jumlah koloni kuman sebelum dan setelah perlakuan pemberian larutan kombinasi larutan kombinasi Chlorexidine gluconate cetrimide alkohol $70 \%$ dan Povidone iodine 10 $\%$.

Ini membuktikan bahwa tiaptiap kelompok sampel sesudah diberi perlakuan, penurunan jumlah koloni kuman relatif berbeda pada kedua kelompok perlakuan. Secara efektifitas lebih baik pada kelompok kombinasi Chlorexidine gluconate cetrimide alkohol $70 \%$ karena memiliki nilai signifikan $(p=0,014)$ yang lebih baik dibandingkan pada kelompok Povidone iodine $10 \% \quad(p=0,041) \quad$ dalam menurunkan jumlah koloni kuman.
Pada Tabel 4 dilakukan analisis statistik membandingkan hasil kepadatan kuman pada swab ke 2 atau pasca perlakuan terhadap kedua kelompok (kelompok larutan kombinasi Chlorexidine gluconate cetrimide alcohol 70\% (clor) dan pada kelompok Povidone iodine $10 \quad \% \quad$ (pov) ). Didapatkan hasil $\mathrm{P}<0,05(\mathrm{P}=0,002)$, Hal ini menunjukkan bahwa ada perbedaan yang bermakna pada jumlah koloni kuman setelah perlakuan baik pada kelompok clor dan kelompok pov.

Pemberian larutan kombinasi larutan kombinasi Chlorexidine gluconate cetrimide - alkohol $70 \%$ memiliki mean $=0,0625$ dan pada kelompok Povidone iodine $10 \%$ Mean $=1,0625$. Hal ini menyatakan bahwa rata-rata penurunan kepadatan kuman pasca perlakuan pada kelompok clor lebih kecil bila dibandingkan pada kelompok pov, dimana secara efektifitas lebih baik pada kelompok kombinasi Chlorexidine gluconate cetrimide - alkohol $70 \%$ karena dalam menurunkan kuman mendekati 0 atau steril.

Pada penelitian ini juga di hitung jumlah koloni kuman pada cairan serebrospinal pasca pemberian kedua larutan desinfeksi, yang mana di dapat kan hasil yang steril atau tidak ditemukan koloni kuman sama sekali.

Efektifitas larutan antiseptik adalah hal yang penting untuk mencegah infeksi. Kolonisasi kuman pada kulit sangat beresiko 
Tabel 2. Hasil Perhitungan kepadatan kuman kelompok Povidone Iodine 10\%

\begin{tabular}{llll}
\hline NO SAMPEL & SWAB 1 & SWAB 2 & CSF \\
\hline 1 & 49 & 1 & 0 \\
\hline 5 & 3 & 3 & 0 \\
\hline 6 & $>>300$ & 4 & 0 \\
\hline 8 & 1 & 0 & 0 \\
\hline 9 & 21 & 0 & 0 \\
\hline 10 & 15 & 0 & 0 \\
\hline 12 & 18 & 0 & 0 \\
\hline 18 & $>>300$ & 8 & 0 \\
\hline 20 & 12 & 0 & 0 \\
\hline 27 & 0 & 0 & 0 \\
\hline 28 & 12 & 0 & 0 \\
\hline 29 & 11 & 0 & 0 \\
\hline 30 & 0 & 0 & 0 \\
\hline 31 & 7 & 0 & 0 \\
\hline 32 & 3 & 1 & 0 \\
\hline
\end{tabular}
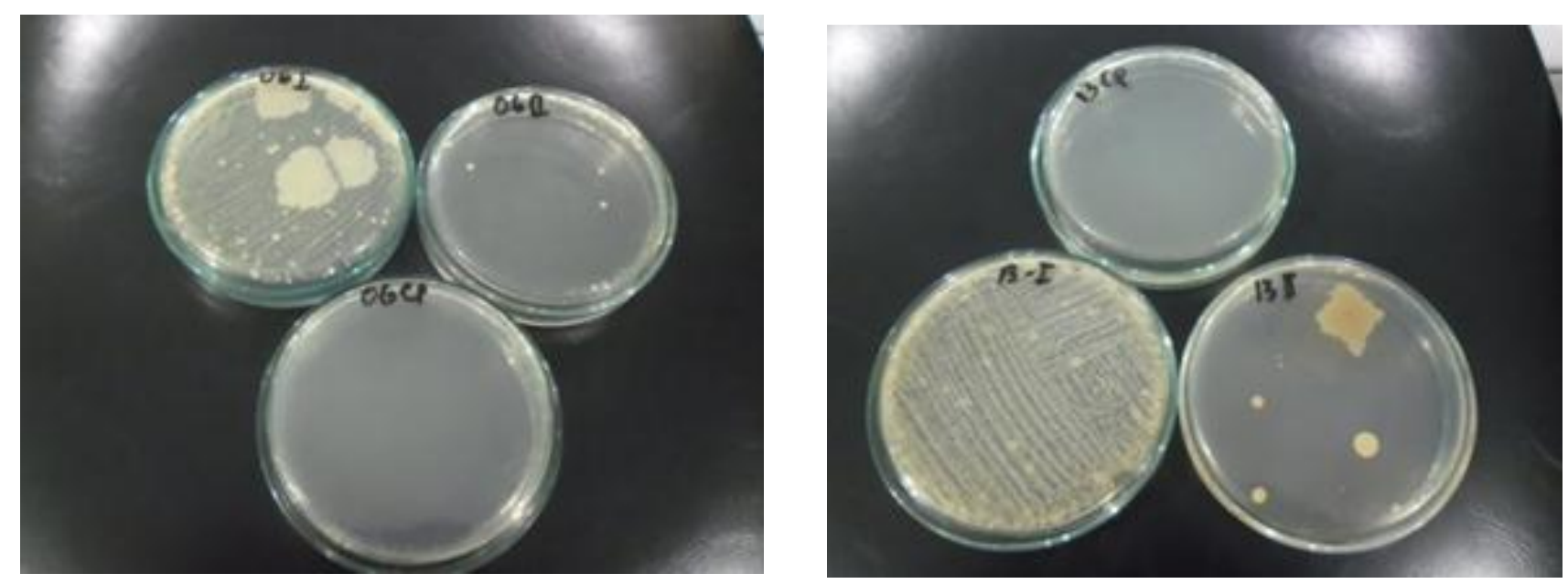

Gambar 2. koloni kuman kelompok (pov), kelompok 6 dan 13 
mengkontaminasi saat tindakan spinal anestesi dilakukan yang dapat mengakibatkan bakteri berpindah lokasi ke lingkungan yang baru dan dapat tumbuh sebagai kuman patogen. Berdasarkan penelitian perbandingan perlakuan antara pemakaian larutan antiseptik kombinasi Chlorexidine gluconate cetrimide - alkohol 70\% dan Povidone iodine $10 \%$ untuk menekan pertumbuhan koloni kuman pada tindakan anestesi spinal.

Dari perbandingan hasil kultur kuman pasca perlakuan di dapatkan kelompok (clor) lebih baik bila dibanding kelompok (pov), dimana dari 16 sampel kelompok clor, hanya 1 kelompok yang masih tersisa 1 koloni kuman pada swab 2, sedangkan pada kelompok pov masih tersisa 4 kelompok sampel yang terdapat koloni kuman. Pada uji statistik dengan uji t berpasangan nilai signifikansi kelompok (clor) $\mathrm{p}=0,014$, sedangkan kelompok (pov) nilai signifikansi $\mathrm{p}=$ 0,041, yang juga memiliki makna pada kelompok (clor) terdapat penyimpangan atau resiko pertumbuhan koloni kuman 1,4\% yang lebih rendah bila dibandingkan pada kelompok (pov) penyimpangan atau resiko pertumbuhan koloni kuman 4,1 \%.

Pada analisis statistik (Tabel 3) yang membandingkan hasil kepadatan kuman pada swab ke 2 atau pasca perlakuan terhadap kedua kelompok (kelompok larutan kombinasi Chlorexidine gluconate cetrimide alcohol 70\% (clor) dan pada kelompok
Povidone iodine $10 \quad \% \quad$ (pov) ). Didapatkan hasil rata-rata penurunan kepadatan kuman setelah perlakuan pada kelompok clor memiliki efektifitas yang lebih baik dibandingkan pada kelompok pov. Larutan kombinasi Chlorexidine gluconate cetrimide alkohol $70 \%$ memiliki mean $=0,0625$ dan pada kelompok Povidone iodine $10 \%$ Mean $=1,0625$. Hal ini menyatakan bahwa rata-rata penurunan kepadatan kuman pasca perlakuan pada kelompok clor lebih kecil bila dibandingkan pada kelompok pov, dimana secara efektifitas lebih baik pada kelompok kombinasi Chlorexidine gluconate cetrimide - alkohol $70 \%$ karena dalam menurunkan kuman mendekati 0 atau steril.

Adler (2012) melakukan penelitian serupa membandingkan kombinasi Chlorexidine-Alkohol dengan povidone iodine untuk antiseptik pada kulit mendapatkan hasil penurunan kuman yang lebih signifikan pada kelompok Chlorexidine $(1,4 \%$ vs 3,3\%) (Adler, 2012). Pada penelitian lain Langgartner et al (2012) menemukan pertumbuhan koloni bakteri pada kateter epidural lebih rendah pada kelompok Chlorexidinealkohol bila dibandingkan dengan povidone iodine $(4,7 \%$ vs $30,8 \%) .^{5}$

Pemberian larutan desinfeksi dengan menggunakan kombinasi Chlorexidine gluconate cetrimide alkohol 70\% memiliki efektifitas yang lebih baik dalam menurunkan koloni kuman bila di bandingkan penggunaan 
Tabel 3. Hasil Uji Statistik Membandingkan kedua kelompok sebelum dan sesudah perlakuan

\begin{tabular}{lllllll}
\hline $\begin{array}{l}\text { Kultur } \\
\text { Bakteri }^{(1)}\end{array}$ & Mean Swab 1 & $\begin{array}{l} \pm \text { Std. } \\
\mathrm{dev}\end{array}$ & $\begin{array}{l}\text { Mean } \\
2\end{array}$ & $\begin{array}{l}\text { Swab } \\
\pm \text { Std. } \\
\text { dev. }\end{array}$ & $\begin{array}{l}\text { Uji Statistik } \\
(\mathrm{p})\end{array}$ \\
\hline Kelompok & 93,18 & $\pm 133,9$ & 0,0625 & $\pm 0,25$ & 0,014 \\
& & & & & \\
\hline Kelompok & 58,0 & $\pm 103,6$ & 1,0625 & $\pm 2,2$ & 0,041 \\
\hline
\end{tabular}

Keterangan :

${ }^{(1)}$ paired sample T test

Jika nilai $\mathrm{p}<0,05$ berarti ada perbedaan yang bermakna dan jika nilai $\mathrm{p}>0,05$ berarti tidak ada perbedaan yang bermakna

Tabel 4. Hasil Uji Statistik Membandingkan Kedua Kelompok Setelah Perlakuan

\begin{tabular}{llll}
\hline Kultur Bakteri Swab 2 & Rata-rata & $\begin{array}{l} \pm \text { Std. } \\
\text { Dev }\end{array}$ & Uji Statistik (p) \\
\hline Kelompok clor & 0,0625 & $\pm 0,0625$ & 0,002 \\
\cline { 1 - 3 } Kelompok pov & 1,0625 & $\pm 1,0625$ & \\
\hline
\end{tabular}

Keterangan :

Dengan independent sample $\mathrm{T}$ test

Jika nilai $\mathrm{p}<0,05$ berarti ada perbedaan yang bermakna dan jika nilai $\mathrm{p}>0,05$ berarti tidak ada perbedaan yang tidak bermakna

Tabel 5. Tabel perbandingan biaya

\begin{tabular}{ll}
\hline & Harga/ liter \\
\hline Kelompok Clor & alkohol $70 \% 800 \mathrm{ml}=\mathrm{Rp} .14 .700$ \\
& savlon Pekat $35 \mathrm{ml}=\mathrm{Rp} .6 .888$ \\
& aquades $165 \mathrm{ml}=\mathrm{Rp} .1000$ \\
& Total Rp.22.588/liter \\
& \\
\hline
\end{tabular}

Kelompok Pov Rp.188.700 
larutan Povidone iodine $10 \%$, disebabkan Chlorhexidine gluconate merupakan larutan antiseptik yang kuat dan berspektrum luas, efektif melawan hampir semua bakteri (gram positif dan gram negatif) dan jamur nosokomial. Senyawa dalam chlorhexidine gluconate secara efisien mengubah permeabilitas dinding sel, serta secara cepat mengendapkan komponen membran sel dan sitoplasma. Pada penambahan isopropyl alkohol akan lebih meningkatkan efek bakterisidal tersebut. Salah satu keunggulan dari chlorhexidine adalah kemampuannya untuk menembus stratum corneum, sehingga menambah durasi kerjanya selama beberapa jam setelah digunakan. Secara umum, bahan tersebut menyebabkan beberapa reaksi kulit yang lebih ringan dibandingkan bahan lain dan bekerja tetap efektif walaupun dengan adanya bahan organik seperti darah atau bahan protein lain ${ }^{2}$

Pada tabel 1 menunjukkan hasil perhitungan kuman baik pada kelompok Chlorexidine-alkohol maupun pada kelompok povidone iodine terdapat nilai ekstrim pada swab 1 , dimana jumlah koloni kuman $>300$ (6 sampel), hal ini berhubungan dengan lama pasien dirawat di rumah sakit (length of stay) lebih dari 3 hari. Terdapat 4 pasien yang sudah dirawat inap 5 hari,dan 2 pasien selama 4 hari. Hal ini membuktikan bahwa lamanya rawat inap meningkatkan jumlah koloni kuman dan resiko terjadi infeksi nasokomial .6 Hal ini sesuai pada penelitian Rahmawanti

(2007)

menunjukkan adanya hubungan yang bermakna antara resiko infeksi nasokomial dengan lama perawatan. ${ }^{7}$

Hasil dari kultur cairan serebrospinal setelah perlakuan pada kedua larutan desinfeksi, baik pada kelompok Chlorexidine cetrimide gluconate- alkohol 70\% dan kelompok povidone iodine $10 \%$ adalah tidak ditemukannya koloni bakteri pada kedua kelompok. Yang mengindikasikan bahwa baik tehnik desinfeksi, peralatan yang digunakan dan larutan desinfeksi dalam kondisi yang steril tidak terkontaminasi bakteri.

Dilakukan juga perbandingan dari segi biaya antara kedua kelompok, Pada Tabel 5 Efektifitas biaya penggunaan kedua larutan desinfeksi kombinasi Chlorexidine gluconate cetrimide - alkohol 70\% memiliki biaya yang lebih murah bila dibandingkan dengan kelompok Povidone iodine $10 \%{ }^{8}$

Dari pembahasan ini Larutan antiseptik kombinasi Chlorexidine gluconate cetrimide- alkohol 70\% memiliki biaya yang lebih murah dan menurunkan jumlah kepadatan kuman lebih rendah dibandingkan dengan larutan Povidone Iodine 10\%

\section{SIMPULAN}

Efektifitas Larutan antiseptik kombinasi Chlorexidine gluconate cetrimide- alcohol $70 \%$ lebih baik bila dibandingkan dengan larutan Povidone 
iodine $10 \%$ terhadap kepadatan kuman pada tindakan anestesi spinal.

\section{DAFTAR PUSTAKA}

1. Tsen, L.C., and Capiello, E. 2007. Complication and Side Effect Of Central Neuraxial Technique. in Wong, CA (editor). Spinal and Epidural Anesthesia. Philadelphia : Mcgraw Hill. p. $184-250$

2. Helb, J.A. 2006. The Importance and Implication of Aseptic Technique During Regional Anesthesia. Regional anesthesia and Pain Medicine. 31:311323

3. ECRI, Institute. 2012. Dura Prep and Chlora Prep Skin Antiseptics For Preventing Surgical Site Infection. ECRI Institute, Hot Line Response. p. 2 $-5$

4. Kulkani, A., and Awobe, R. 2013. A Prospective Randomised Trial To Compare The Efficacy Of Povidone Iodine $10 \%$ and Chlorhexidine $2 \%$ for Skin Disinfection. Indian Journal Of Anesthesia. 57: 2-4

5. Langgartner, J. 2012. Combine Skin Disinfection with Chlorexidine and Aqueous Povidone Iodine Reduces Bacterial Colonisation of Central Venous Catheter. Intensive Care Med;30:1081-8

6. .WHO. 2009. WHO Guidelines For Safe Surgery. P. 70-78

7. Rahmawati, F.J. 2007. Infeksi Nasokomial dan Pengendaliannya. Jakarta:Salemba Medika
8. Depo Farmasi RSSA. 2014. Daftar Harga Obat. Rumah sakit Saiful Anwar Malang. 